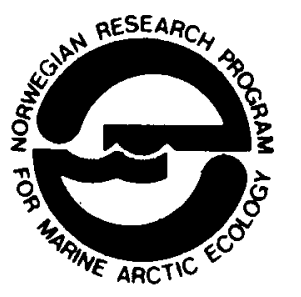

\title{
Proceedings of the Pro Mare Symposium on Polar Marine Ecology, Trondheim, Norway, 12-16 May 1990
}

\section{Preface}

Pro Mare, the Norwegian Research Program for Marine Arctic Ecology, began in 1984 and was concluded in 1989. The aim of the program was to increase our understanding of how pelagic ecosystems function in the Arctic seas, thereby improving the basis for government decision-making as well as elevating scientific competence both with respect to fish stock management and for evaluation of the effects of pollution. The program gave priority to longterm research on systems ecology, with some emphasis on physiological ecology. It accordingly operated in the border zone between pure and applied research with emphasis in terms of methodology on the former. Pro Mare focused on the Barents Sea and the adjacent coastal waters of Svalbard.

Pro Mare is the most comprehensive marine ecological research program ever carried out in Norway, both with regard to manpower and to funding. Norwegian participation amounted to 32 man-years during each of the six years of Pro Mare's operation; of these, 22 were salaried by Pro Mare. In addition, 15 foreign scientists were involved on a relatively regular basis. The scientific tasks covered all aspects of the pelagic ecosystem, from the microbial-loop, sedimentation, nitrogen cycling and plankton production to fish, seals, seabirds, oil pollution and mathematical modelling. Pro Mare was a nationally coordinated program with participating scientists from the universities of Bergen, Oslo, Troms $\emptyset$ and Trondheim as well as the Institute of Marine Research in Bergen and the Norwegian Polar Research Institute in Oslo.

The total cost of the program was about 95 million NOK, 40 million of which was provided by the initiators of the program: the Norwegian Fisheries Research Council, the Norwegian Research Council for Science and the Humanities, and the Ministry of the Environment. The remaining 50 million NOK mainly represented ship-time provided by the Institute of Marine Research, the Norwegian Polar Research Institute, the universities of Bergen and Troms $\emptyset$, and the Norwegian Coast Guard.

The Pro Mare program was concluded with an international Symposium on Polar Marine Ecology, held from 12-16 May 1990 in Trondheim. The Symposium attracted 150 participants from Norway and abroad, and 95 papers and posters were presented. 52 of the symposium contributions are published in these Proceedings. The editors hope that this Pro Mare Proceedings volume will be of value to colleagues in the field of polar marine ecology, and not least to contemporary and future students involved in this field of research.

The editorial committee gratefully expresses its thanks to the Norwegian Fisheries Research Council, the Norwegian Research Council for Science and the Humanities, and the Ministry of Environment for the grants that made Pro Mare, including the Symposium and the publication of the Proceedings, possible. We also appreciate the benevolence of Norsk Hydro a.s and A/S Norske Shell for grants which gave additional support to the arrangement of the Symposium and the publication of the Proceedings.

\section{August 1991}

Egil Sakshaug Christopher C.E. Hopkins Nils Are Øritsland 
Egil Sakshaug

Trondhjem Biological Station

University of Trondheim

The Museum

N-7018 Trondheim, Norway

Christopher C.E. Hopkins

Norwegian College of Fishery Science

University of Troms $\emptyset$

Dramsveien 201

N-9000 Tromsø, Norway

Nils Are Øritsland

Norwegian Polar Research Institute

P.O. Box 158

N-1330 Oslo Lufthavn, Norway

ISSN 0800-0395

Printed December 1991 
D. Aksnes, Bergen, Norway

V. Alexander, Fairbanks, USA

U. Båmstedt, Bergen, Norway

T.R. Bell, Uppsala, Sweden

P.K. Bjørnsen, Elsinore, Denmark

H. Blackburn, Aarhus, Denmark

F. Buchholz, Kiel, FRG

J.S. Christiansen, Troms $\varnothing$, Norway

A. Clarke, Cambridge, UK

L. Codispoti, Monterey, Mexico

R.J. Conover, Dartmouth, Canada

I. Dundas, Bergen, Norway

K.W. Estep, Bergen, Norway

H.G. Fransz, Texel, Netherlands

K. Fugelli, Oslo, Norway

B. Gulliksen, Troms $\varnothing$, Norway

W. Hagen, Kiel, FRG

W.G. Harrison, Dartmouth, Canada

J. Harwood, Cambridge, UK

B.R. Heimdal, Bergen, Norway

J. Henderson, Stirling, UK

O. Holm-Hansen, La Jolla, USA

G. Hubold, Hamburg, FRG

G.L. Hunt, Irvine, USA

M. Jobling, Tromsø, Norway

O.M. Johannesen, Bergen, Norway

H.K. Johnsen, Troms $\emptyset$, Norway

G. Kattner, Bremerhaven, FRG

D.A. Kiefer, Los Angeles, USA

S. Kristiansen, Oslo, Norway

C. Lancelot, Brussels, Belgium

D. Lavigne, Guelph, Canada

P. LeVasseur, Mont Joli, Canada

J. Leverenz, Umeå, Sweden

R. Lichtenthaler, Oslo, Norway

G. Lilly, St. John's, Canada

J.A. Lindley, Plymouth, UK

L. Madin, Woods Hole, USA

J. Mauchline, Oban, UK

T. McClimans, Trondheim, Norway
F. Mehlum, Oslo, Norway

J. Morison, Seattle, USA

M. Mork, Bergen, Norway

E.M. Nilssen, Tromsø, Norway

E. Nordøy, Troms $\emptyset$, Norway

F. Norrbin, Troms $\emptyset$, Norway

A. North, Cambridge, UK

K. Østgård, Trondheim, Norway

Y. Olsen, Trondheim, Norway

E. Paasche, Oslo, Norway

T. Packard, Mount Joli, Canada

O.K. Pálsson, Reykjavik, Iceland

S. Pearre, Halifax, Canada

D. Pierson, Uppsala, Sweden

T. Platt, Dartmouth, Canada

B. Riemann, Hørsholm, Denmark

J.R. Rainusso, Trondheim, Norway

K. Ronald, Guelph, Canada

J. Runge, Mont Joli, Canada

M.S. Ryg, Olso, Norway

D. Sameoto, Mont Joli, Canada

T. Schram, Oslo, Norway

D. Slagstad, Trondheim, Norway

W.M. Smethie, Palisades, USA

S.L. Smith, Upton, USA

T.G. Smith, Québec, Canada

C.W. Sullivan, Los Angeles, USA

A. Svansson, Gothenburg, Sweden

N. Swanberg, Bergen, Norway

K.S. Tande, Troms $\varnothing$, Norway

T.F. Thingstad, Bergen, Norway

M.M. Tilzer, Konstanz, FRG

H.A. Thomsen, Copenhagen, Denmark

J. Throndsen, Oslo, Norway

O. Vadstein, Trondheim, Norway

P.J. Verity, Savannah, USA

J.J. Walsh, St. Petersburg, USA

P. Ward, Cambridge, UK

J.E. Weber, Oslo, Norway 
